\title{
Globalization dynamics in times of crisis
}

\author{
Boris A. Kheyfets ${ }^{\mathrm{a}, \mathrm{b}}$ and Veronika Yu. Chernova ${ }^{\mathrm{c}, \mathrm{d}^{*}}$
}

anstitute of Economics of the Russian Academy of Sciences, Russian Federation

${ }^{b}$ Financial University under the Government of the Russian Federation, Russian Federation

'Department of Marketing, Peoples' Friendship University of Russia (RUDN University), Russian Federation

${ }^{d}$ Department of Advertising and Public Relations, State University of Management, Russian Federation

\begin{abstract}
A B S T R A C T
The slowdown in globalization preceded by the 2008-2009 financial crisis and accompanied by stagnation in cross-border flows of goods and investments ignited the scientific debate about globalization shutting down. This paper assesses globalization on the basis of the observed flows of investment, data, population and trade for the period of 1998-2018. To do so, we propose the Index of Globalization (IG) that allowed us to highlight the key trends in the global economic development. Our assessments show that there was a sustained decline in the trade and investment components of globalization. The information flow demonstrates a slowdown in developed economies, but its growth rate remains stably high. The IG dynamics indicates a significant decrease in times of crises. In contrast to the 2008-2009 financial crisis and the outbreak of SARS in 2003, the COVID-19 pandemic has already caused a more considerable reduction in international flows of factors of production and global GDP. The changes in society behavior adopted during the COVID-19 spread are forecast to have long-term consequences. In terms of globalization, the pandemic has positively affected the dynamics of the information flow by increasing volumes of Internet traffic and intensifying the use of communications. The research results demonstrate that in the case of a significant slowdown in the trade, investment and population flows, an increase in the information flow will not have a substantial impact on globalization processes and will be unable to break the overall trend towards a decline in the Index of Globalization.
\end{abstract}

(C) 2020 by the authors; license Growing Science, Canada.

\section{Introduction}

According to some estimates, the era of globalization started in 1980 and ended with the 2008-2009 financial crisis (Kheyfets, 2018). The stagnation of cross-border flows of goods and investments coming afterwards was termed slowbalisation and sparked a scientific discussion about the end of the era of globalization (see, e.g. Hammes, 2016; King, 2017; D'Urbino, 2019). According to the experts from The Economist (D'Urbino, 2019), the slowdown in trade from light speed to a snail's pace is of structural nature and caused by the following factors: a decrease in imports by emerging countries and transitional economies; a shift in economic activity towards services, which are harder to sell across borders; trade and sanction wars; deepening links within regional blocs.

These processes have a number of negative consequences. Until recently, climate change and illegal immigration from third-world countries and hot spots have been among the acutest global problems (Hadili, Raab \& Wenzelburger, 2016; Makreshanska-Mladenovska \& Petrevski, 2017; Orazbayev, 2017; Ali \& ur Rehman, 2018; Watanabe, Miyake \& Yasuoka, 2018). But today, counteracting the spread of COVID-19 and the subsequent economic recovery are the most important

* Corresponding author

E-mail address: veronika.urievna@mail.ru (V. Y. Chernova)

C 2020 by the authors; licensee Growing Science.

doi: $10.5267 /$ j.uscm.2020.5.004 
tasks requiring all nations to collaborate. The purpose of the study, therefore, is to assess globalization of actually observed flows prior to the spread of COVID-19 and attempt to provide a forecast about the upcoming stage of globalization.

\section{Literature review}

Globalization is a dynamic process, where national economies integrate through trade, investment, information and other flows (Lankauskiene \& Tvaronavičiene, 2012; Tvaronavičiene, Grybaite \& Tunčikiene, 2013; Huh \& Park, 2019; Zeibote, Volkova \& Todorov, 2019). Most researchers acknowledge that globalization originates deep in history (Sheffield, Korotayev \& Grinin, 2013), although opinions about its periodization vary (Friedman, 2005; Chumakov, 2014; Altman, Bastian, 2019). As Kheyfets (2018) puts it, the modern stage of globalization differs fundamentally from the earlier processes of internationalization. The specifics of globalization happening today is explained by its novel form: economic activity not only expands across national borders, but also splits the production process into fragments (Robinson, 2011).

It is worth noting that all approaches to the periodization of globalization emerged after the term was firmly entrenched in the scientific literature. To date, no single definition of globalization has been proposed. Globalization is an extremely complex and multifaceted process that covers all aspect of socio-economic life. It is little wonder that a wide array of variables is applied to measure and evaluate it (Simonova, 2009). Shulgin, Zinkina and Andreev (2019) develop an approach to evaluating globalization from the standpoint of its intensity. Gichiev (2014) proposes the Integral Index of Globalization. In order to assess globalization, some experts apply single indices, e.g. international trade indicators (Arribas, Perez \& Tortosa-Ausina, 2009), financial globalization indicators exclusively (Maslov, 2001; Ayhan Kose et al., 2006) or economy openness indicators (Andersen \& Herbertsson, 2003; Chinn \& Ito, 2008). Other researchers (Martens, Dreher \& Gaston 2008; Vujakovic, 2010; Caselli, 2006) attempt not only to gauge economic globalization, but also consider socio-cultural aspects, political factors, citizens personal contacts, and technological development.

For instance, the KOF Index of Globalisation created in 2002 by Swiss Economic Institute and Swiss Federal Institute of Technology is based on three principal globalization criteria - economic, social and political (Savina et al., 2019; Dreher, 2006). The index is calculated as the sum of the criteria with weights of $36 \%, 39 \%$ and $25 \%$, respectively. Within this approach, globalization is viewed as a process that moves across national borders, unites economies, politics, technologies, flows of goods, capital and people, and creates cultural flows (Dreher et al., 2010). According to Randolph (2001), the assessment of globalization can incorporate telephone traffic and Internet hosts.

Another globalization index - The A.T. Kearney/Foreign Policy Globalization Index - was developed by the international consulting company A.T. Kearney. The index uses groups of variables, including indicators of political and economic integration, social and cultural factors, geographical specifics of countries, the level of technological development, and environmental situation (Dreher, Gaston \& Martens, 2008). Vujakovic (2010) scrutinizes the issue of assessing globalization and designs the New Globalization Index (NGI) consisting of 21 indicators. In addition to purely economic indicators, Vujakovic applies a number of additional criteria, such as international student mobility and environmental issues. The NGI uses geographical distances between trading partners as weights. As a result, the author finds a significant downward movement in the ranking of some EU countries, since their international openness is dependent on trade within their region and reflects regional integration.

The CSGR Index was developed by the University of Warwick, UK (n.d.). On the basis of regression analysis, it allows investigating the relationship between globalization and key economic variables, such as economic growth, inequality, and government spending. The CSGR Index measures the economic, social and political dimensions of globalization.

All the above-mentioned globalization indices reflect a particular stage in the scientific understanding of globalization and can serve as the basis for further research in this field.

\section{Materials and Methods}

Globalization characterizes the processes of strengthening countries' economic integration and their interdependence. The literature review shows that both inflows and outflows of factors are highly important when assessing globalization. Within the framework of the current research, it is of special interest to assess the globalization of the major factor flows that cover the central aspects of foreign activity and for which reliable data for a prolonged period are available. These factors are trade in goods and services, and investment, information and population flows. In their integral shape, they form some kind of the Index of Globalization (IG):

$$
I G=\sqrt[4]{I G_{G S} \times I G I \times I G I I \times I G P},
$$

where $I G_{G S}$. is the index of globalization of trade; $I G I$ is the index of globalization of investment; $I G I I$ is the index of globalization of information; $I G P$ is the index of globalization of population (Table 1). 
Table 1

Components of the Index of Globalization (IG)

\begin{tabular}{ll}
\hline Indicators of flows & Notation \\
\hline Trade flow & $I G_{G S}$ \\
\hline 1. Sub-index of globalization of trade & $G S_{i}^{e x}$ \\
1.1. Outflow of goods and services (exports) & $G S_{i}^{\text {imp }}$ \\
\hline 1.2. Inflow of goods and services (imports) & $I G I$ \\
\hline Investment flow & $F D I_{i}^{\text {in }}$ \\
\hline 2. Sub-index of globalization of investment & $F D I_{I}^{\text {out }}$ \\
\hline 2.1. Inflow of FDI & \\
\hline 2.2. Outflow of FDI & $I G I I$ \\
\hline Information flow & $P_{I I}$ \\
\hline 3. Sub-index of globalization of information & $I G P$ \\
3.1. Number of Internet users & $T_{i}^{\text {dep }}$ \\
\hline Population flow & $T_{i}^{\text {arr }}$ \\
\hline 4. Sub-index of globalization of population & \\
\hline 4.1. Tourist outflow & \\
\hline 4.2. Tourist inflow & \\
\hline
\end{tabular}

Within the given research, the sub-index of globalization of trade $(I G T)$ is calculated as the root-mean-square product of the growth rate of the inflow and outflow of goods and services by formula:

$$
\begin{aligned}
I G_{G S} & =\sqrt{\left(\frac{G S_{i}^{e x}}{G S_{i-1}^{e x}}\right) \times\left(\frac{G S_{i}^{i m p}}{G S_{i-1}^{i m p}}\right)}, \\
G S_{i}^{e x} & =\frac{G S_{i}^{e x}}{G D P_{i}}, G S_{i}^{i m p}=\frac{G S_{i}^{i m p}}{W I_{i}},
\end{aligned}
$$

where $I G_{G S}$ denotes the index of globalization of trade in goods and services; $G S_{i}^{e x}$ denotes the outflow of goods and services (exports); $G S_{i}^{i m p}$ denotes the inflow of goods and services (imports); $G D P_{i}$ denotes the country's GDP; $W I_{i}$ denotes the volume of global imports.

The sub-index of globalization of investment $(I G I)$ is calculated as the root-mean-square product of the growth rate of the inflow and outflow of foreign direct investment (FDI):

$$
I G I=\sqrt{\left(\frac{F D I_{i}^{\text {in }}}{F D I_{i-1}^{\text {in }}} \times \frac{F D I_{i}^{\text {out }}}{F D I_{i-1}^{\text {out }}}\right)},
$$

where $I G I$ is the index of globalization of investment flow; $F D I_{i}^{\text {in }}$ is the inflow of FDI; FDI $I_{I}^{\text {out }}$ is the outflow of FDI. Over the last 15 years, the increase in information flows has been due to the assimilation of the Internet technologies and digitalization of economy. Accordingly, a number of indicators were used to describe modern information globalization, such as the volume of cross-border Internet traffic and telephone communications, the volume of Internet trade, the number of Internet users, etc. In the present research, we use the specific indicator of Internet users for the sub-index of globalization of information $(I G I I)$ :

$$
I G I I=\frac{\frac{P_{I I i}}{P_{i}}}{\frac{P_{I I(i-1)}}{P_{i-1}}},
$$

where $P_{I I i}$ is the number of Internet users in the country; $P_{i}$ is the country's population. Migration occupies a special role in the population flow. However, the limited availability of reliable data (especially with the illegal migration becoming widespread) did not allow migrant flows to be included in the assessment of globalization of the population. Therefore, the sub-index of globalization of population $(I G P)$ is defined as the root-mean-square product of the growth rate of the official inward and outward-bound tourist flows: 


$$
\begin{aligned}
& I G P=\sqrt{\left(\frac{T_{i}^{d e p}}{T_{i-1}^{d e p}}\right) \times\left(\frac{T_{i}^{\text {arr }}}{T_{i-1}^{a r r}}\right)}, \\
& T_{i}^{\text {dep }}=\frac{P_{i}^{\text {dep }}}{P_{i}}, T_{i}^{\text {arr }}=\frac{P_{i}^{\text {arr }}}{W T_{i}},
\end{aligned}
$$

where $I G P$ is the index of globalization of the tourist flow; $T_{i}^{d e p}$ is the tourist outflow; $T_{i}^{\text {arr }}$ is the tourist inflow; $P_{i}^{d e p}$ is the number of tourists going abroad; $P_{i}$ is the country's population; $P_{i}^{a r r}$ is the number of tourists arriving to the county; $W T_{i}$ is the number of world tourists visiting foreign countries. To assess globalization, we use the statistical databases of the World Bank, the International Monetary Fund, the OECD database, the United Nations Department of Economic and Social Affairs, analytical reports of the management consulting firm McKinsey \& Company, the global logistics company DHL and Cisco.

\section{Results and Discussion}

\subsection{Development trends: A historical perspective}

Although the dynamics of trade in goods and services as a percentage of world output of goods and services decreased in certain periods (2008-2009, and 2014-2016), the overall positive trend has persisted over the past quarter century (Fig. 1). Among recent constraining factors are trade disputes between countries, increased protectionism and the worsening macroeconomic satiation. In 2018, the rise in the turnover amounted to $3.0 \%$ compared with $4.6 \%$ a year earlier and was provided mainly by higher prices.

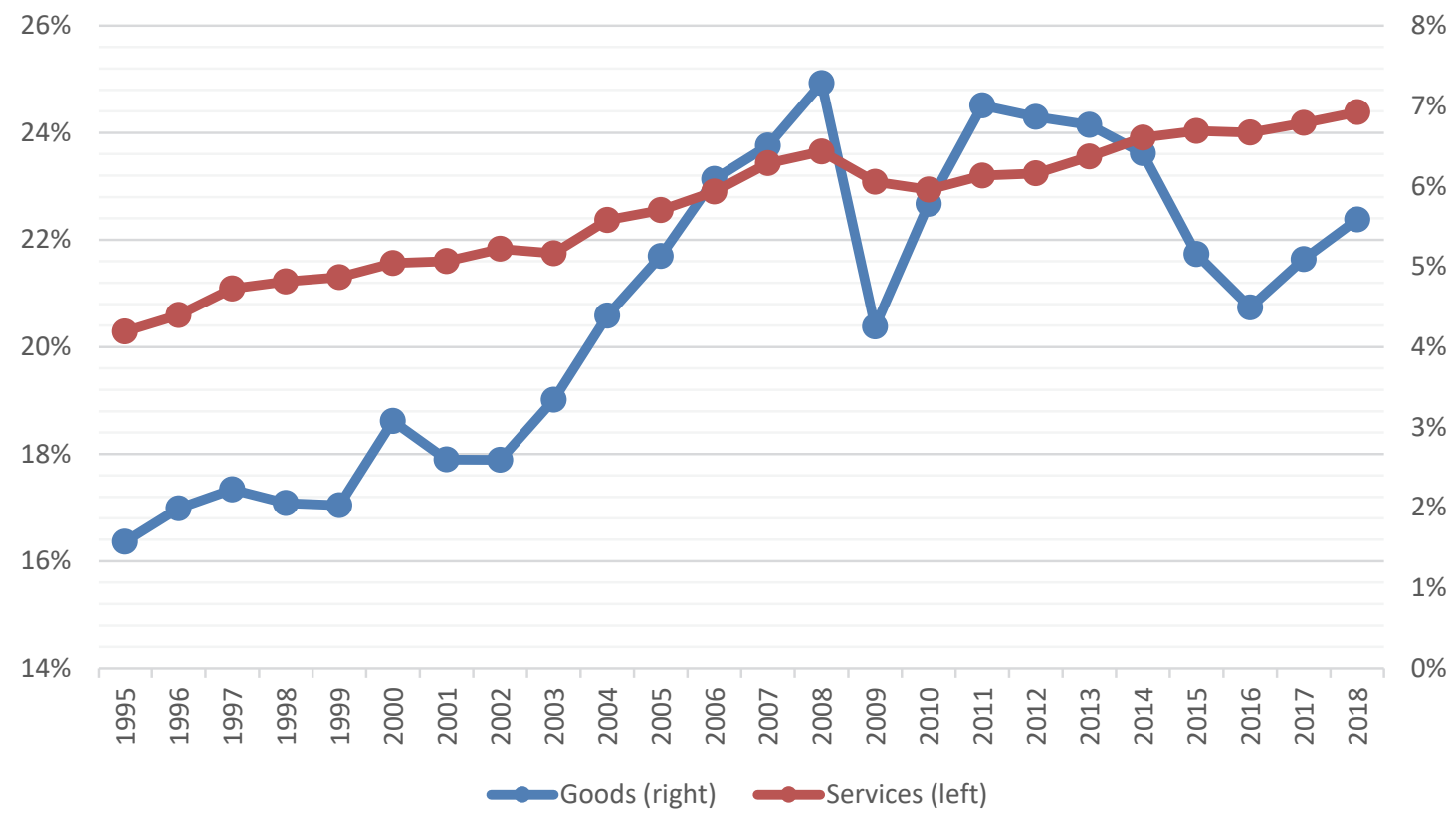

Fig. 1. The share of trade in goods and services in relation to global output

After the 2008-2009 financial crisis, the sub-index of globalization of trade demonstrated a downward trend with a slight recovery in $2017(+1,84 \%)$ and a subsequent slowdown in $2018(+1,53 \%)$ (Table 2$)$. The sub-index of globalization of trade in Russia in 2017-2018 demonstrated an upward trend (+6\%) after the decline in previous years (especially in 2015 by $12 \%$ ) caused by sanctions and the implemented import substitution policy. In 2018, the United Kingdom and the USA exhibited the greatest fall in the sub-index by $1.72 \%$ and $0.55 \%$, respectively. The increase in the IGT was noted in Japan $(+2.12 \%)$, Singapore $(+1.53 \%)$, China and Italy $(+1.02 \%)$. 
Table 2

Dynamics of the sub-index of globalization of trade, $\%$

\begin{tabular}{|c|c|c|c|c|c|c|c|c|c|c|c|}
\hline Country & 2007 & 2008 & 2009 & 2010 & 2011 & 2012 & 2013 & 2014 & 2015 & 2016 & 2017 \\
\hline China & 1.5 & -1.8 & -7.7 & 10.2 & 5.8 & 0.2 & 1.3 & -0.4 & -4.6 & -4.3 & 2.3 \\
\hline Germany & 2.4 & -0.4 & -6.4 & 2.2 & 2.8 & -2.5 & 0.3 & 0.2 & 0.2 & 1.1 & 1.5 \\
\hline France & -0.4 & 0.5 & -6.0 & -0.7 & 2.5 & -2.0 & 0.9 & 0.5 & 2.9 & 1.1 & -0.1 \\
\hline UK & -7.2 & -2.4 & -1.7 & -0.3 & 1.0 & -1.8 & 0.3 & -1.0 & 0.5 & 0.2 & 0.3 \\
\hline Italy & 2.5 & -3.4 & -10.6 & 3.2 & 0.7 & -4.4 & -1.2 & 0.1 & -0.5 & 0.3 & 3.1 \\
\hline Japan & 1.6 & 2.4 & -17.8 & 11.0 & 0.9 & 0.2 & 0.1 & 5.9 & -4.1 & -5.1 & 3.7 \\
\hline South Korea & 3.2 & 15.6 & -5.4 & 5.8 & 10.5 & 0.6 & -4.6 & -5.0 & -8.2 & -5.1 & 3.9 \\
\hline Russia & 2.2 & 8.4 & -12.9 & 6.2 & 1.7 & 1.0 & -0.3 & -2.7 & -11.8 & -6.7 & 5.7 \\
\hline Singapore & -4.9 & 7.1 & -8.0 & 5.2 & 1.3 & -0.6 & 0.2 & -1.7 & -4.4 & -5.0 & 2.5 \\
\hline USA & -0.2 & 1.3 & -7.7 & 6.5 & 2.8 & 0.8 & -1.4 & 0.5 & -0.3 & -2.1 & -0.7 \\
\hline World & 1.7 & 2.2 & -8.2 & 4.1 & 3.5 & -0.3 & 0.1 & -0.5 & -3.0 & -1.8 & 1.8 \\
\hline
\end{tabular}

The increase in globalization of population through more intense cross-border movements is mainly due to the tourist flow (Table 3), which resulted from both an improvement in the visa policy of many countries and a rise in the number of people who could afford travelling abroad (Donnan \& Leatherby, 2019). The sub-index of globalization of the tourist flow was declining during the 2008-2009 financial crisis; however, as early as 2010, it recovered to the pre-crisis level and kept on growing at a steady rate of 3-4\% a year. Russia was the only exception: since the introduction of sanctions, the country has witnessed a sharp decrease in the growth rate of the tourist flow $(-18 \%$ in 2016$)$ followed by its recovery in $2017(+11 \%)$.

Table 3

Dynamics of the sub-index of globalization of population, $\%$

\begin{tabular}{lcccccccccccc}
\hline Country & 2007 & 2008 & 2009 & 2010 & 2011 & 2012 & 2013 & 2014 & 2015 & 2016 & 2017 & 2018 \\
\hline China & 9.7 & 3.0 & 1.7 & 10.8 & 10.1 & 5.7 & 3.9 & 6.1 & 3.4 & 2.8 & 0.3 & 1.0 \\
Germany & 2.0 & 3.5 & -1.6 & 5.6 & 3.0 & 2.2 & 4.6 & -0.6 & 2.9 & 4.7 & 3.2 & 10.3 \\
France & 14.2 & -6.0 & -2.5 & -0.5 & 4.5 & -1.0 & 2.2 & 3.3 & -2.0 & -1.5 & 7.2 & -2.4 \\
UK & - & - & - & - & 2.5 & -0.7 & 4.0 & 4.1 & 7.3 & 5.6 & 3.6 & -2.8 \\
Italy & 6.6 & -0.1 & 2.3 & 1.6 & 2.1 & -0.7 & -1.1 & 1.5 & 3.4 & 4.6 & 10.4 & 5.4 \\
Japan & 5.9 & -3.9 & -11.4 & 16.9 & -14.0 & 21.0 & 8.3 & 12.0 & 18.9 & 13.5 & 11.8 & 7.4 \\
South Korea & 9.4 & -2.3 & -5.5 & 21.4 & 6.0 & 10.6 & 8.4 & 12.0 & 5.5 & 22.7 & -4.4 & 11.4 \\
Russia & 9.6 & 5.0 & -8.1 & 9.4 & 11.5 & 11.1 & 11.0 & -5.6 & -11.6 & -18.4 & 11.4 & 3.2 \\
Singapore & 4.6 & 2.5 & -2.4 & 12.6 & 8.3 & 4.0 & 6.5 & -0.8 & 1.7 & 4.1 & 5.7 & 4.7 \\
USA & 4.8 & 0.9 & -4.1 & 3.0 & 0.9 & 3.6 & 3.6 & 7.8 & 5.6 & 2.7 & 4.7 & 4.2 \\
World & 6.8 & 1.6 & -3.3 & 7.0 & 3.7 & 4.8 & 4.3 & 3.7 & 3.6 & 4.0 & 6.2 & 4.3 \\
\hline & & & & & & & & & & & &
\end{tabular}

Throughout the entire period under review, FDI flow remained extremely unstable and was the only flow that continued to decline after a sharp drop during the 2008-2009 crisis and short-term recovery in 2015.

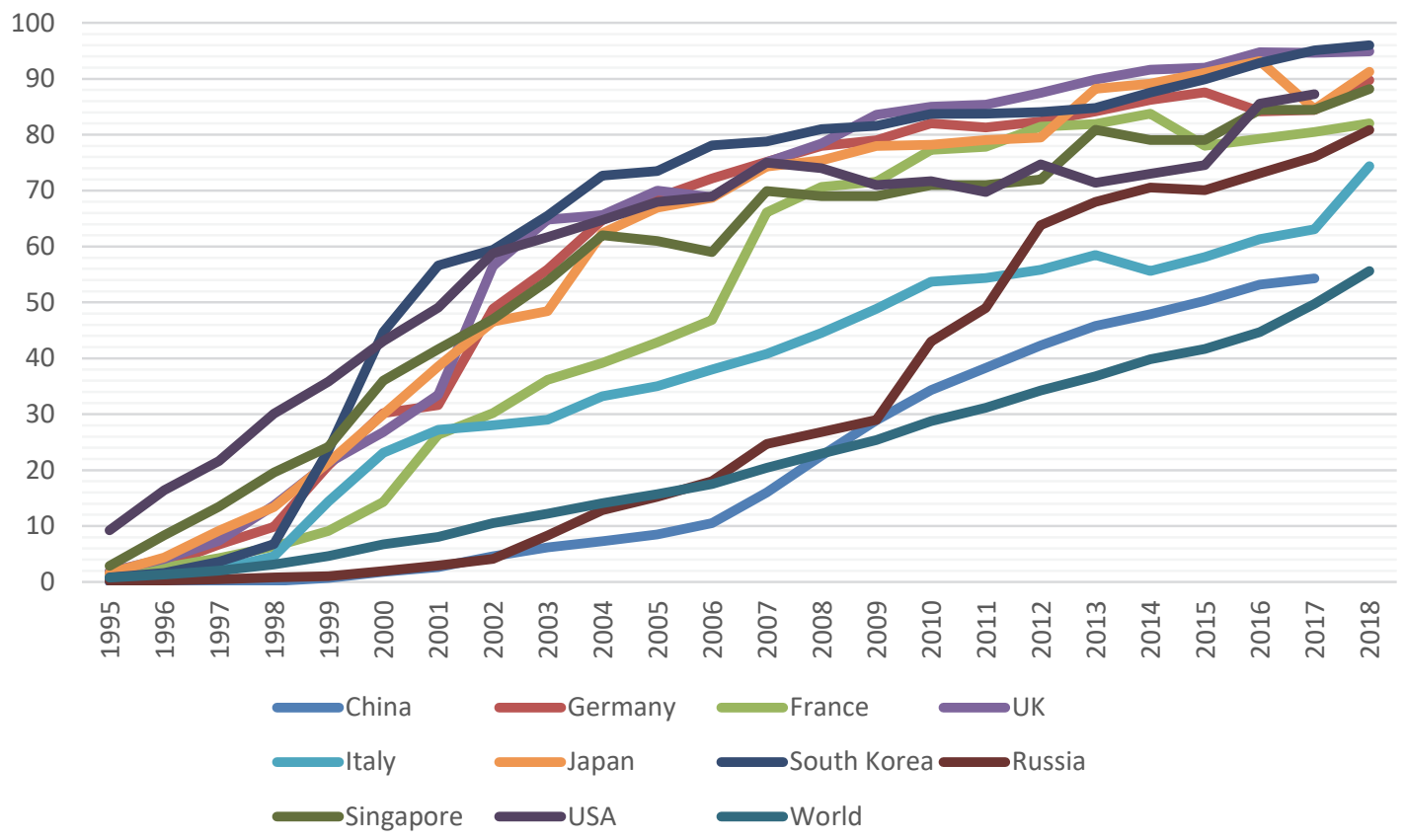

Fig. 2. The share of Internet users, \% of the country's population 
The weakening of trade and investment components of globalization does not mean globalization processes reversed. The growing interdependence of national economies is ensured by the emergence of a new powerful engine, i.e. information flows (Bereznoy, 2018). This applies both to the total volume of global Internet traffic and its cross-border segment. According to Cisco, from 2002 to 2016 the global Internet traffic increased 266 times. In the context of these trends, many researchers have raised the question about a new era of digital globalization, noting that global trade flows have been shaping for centuries and large-scale cross-border digital flows came into existence 15-20 years ago (Lund, Manyika \& Bughin, 2016). The assessment of globalization of information indicates that all the countries have experienced the most dramatic growth (Fig. 2). Most developed nations (the UK, South Korea, Japan, and Germany) saw a rapid growth in the number of Internet users in the late 1990s - the early 2000s, China - from 2006, Russia - from 2009 to 2012; however globally, the number of Internet users is still growing at a fast pace. Thus, the growth rate of globalization of trade and investment flows slows down, whereas the population flow rises by 3-4\% per year. The information flow of developed economies demonstrates a slowdown, but its growth rate remains stably high on a global scale. As a result, globalization is gradually slowing down, as evidenced by the Index of Globalization (Fig. 3).

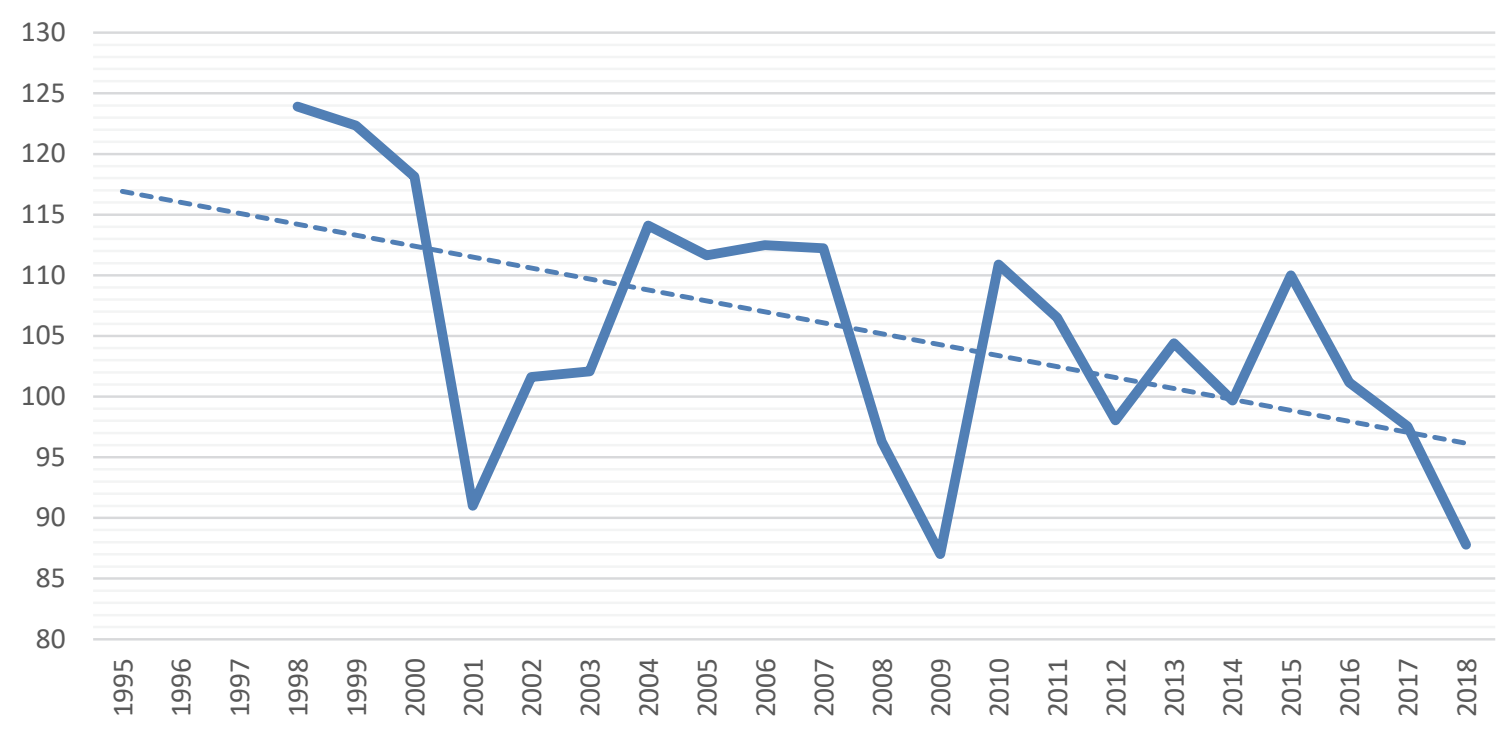

Fig. 3. The Index of Globalization (IG), \%

The $I G$ dynamics shows a significant downturn in times of crises. For example, in 2007-2008, the $I G$ fell by $28.95 \%$, while the indicator of post-crisis globalization was lower than its pre-crisis level $\left(\mathrm{IG}_{2007}=112.22 \%\right.$, whereas $\left.\mathrm{IG}_{2010}=110.88 \%\right)$.

\subsection{Impact of COVID-19}

The outbreak of COVID-19 and restrictive measures against it immediately changed the global economy. One of the most important transformation processes was the accelerated introduction of digital technologies. The disruption of people's freedom of movement and social distancing measures put by many nations forced businesses and consumers to adapt to a new lifestyle and actively employ digital solutions to keep on working remotely. In the first quarter of 2020, there was a surge in downloads of mobile applications and software in China, Italy, Spain and the United States by more than $40 \%$. However, at the end of the year these figures are likely to decline and average $10 \%$ in the USA, $6 \%$ - in Russia and the UK, $4 \%$ - in Japan, and 3\% - in China (Sensortower, 2020).

An increase in Internet access does not necessarily mean digital globalization growing at the same rate. The point is that the Internet is used predominantly for internal communications. For example, only about $15 \%$ of Facebook communications cross national borders; solely about $25 \%$ of Twitter followers live in foreign countries; and only $20 \%$ of popular YouTube videos are ranked among the Top-10 in more than one country (Cisco, 2020). A similar situation is typical of e-commerce, where cross-border sales amount to $11-15 \%$ of all B2C online transactions in the world and $23 \%$ in Europe.

Currently, we can see growing volumes of e-commerce sales. It is noteworthy that in Europe the share of small and mediumsized businesses makes up $99 \%$ of all companies (Litau, 2017, 2018), and, although $77 \%$ of them have corporate websites, only $17 \%$ sell products via the Internet (Cisco, 2020). Nevertheless, as of April 2020, in the USA and Europe there was a significant increase in e-commerce volumes - by $75-100 \%$. Russia experienced the opposite situation: the volumes of ecommerce reduced by $25-50 \%$ (The ACH, 2020). In our opinion, this situation reflects not so much the restrictive measures 

\& Vlasov, 2018).

The use of digital technologies provides extra opportunities to overcome the crisis caused by the spread of COVID-19, but fails to mitigate its consequences completely. Production of computers, electronics, optical products, motor vehicles, textiles, and clothing are the most globally integrated economic sectors, whose recovery may be impeded with low external demand and disruptions of supply chain (OECD, 2018; Romanova, Korovin \& Kuzmin, 2017).

Significant economic downturn is expected in almost every country. According to the Center for Strategic \& International Studies, the COVID-19's harm to the Chinese economy turned out to be worse than initially predicted: automobile sales sank a record $80 \%$, and the country's exports fell 17.2\% (Segal \& Gerstel, 2020). Lower budget revenues and higher government spending taken together can put many countries on the brink of a debt crisis (EIU, 2020). In most OECD countries, $10 \%$ of their employment is driven by final foreign demand. Small countries deeply integrated in global production chains are particularly dependent on external demand. It is forecast that Latin America and the Eurozone, especially Italy, Germany and France, will be among the most affected regions: the manufacturing sector of these countries is largely export-oriented and interruptions of supply coupled with low demand will hamper economic recovery (Fig. 4).

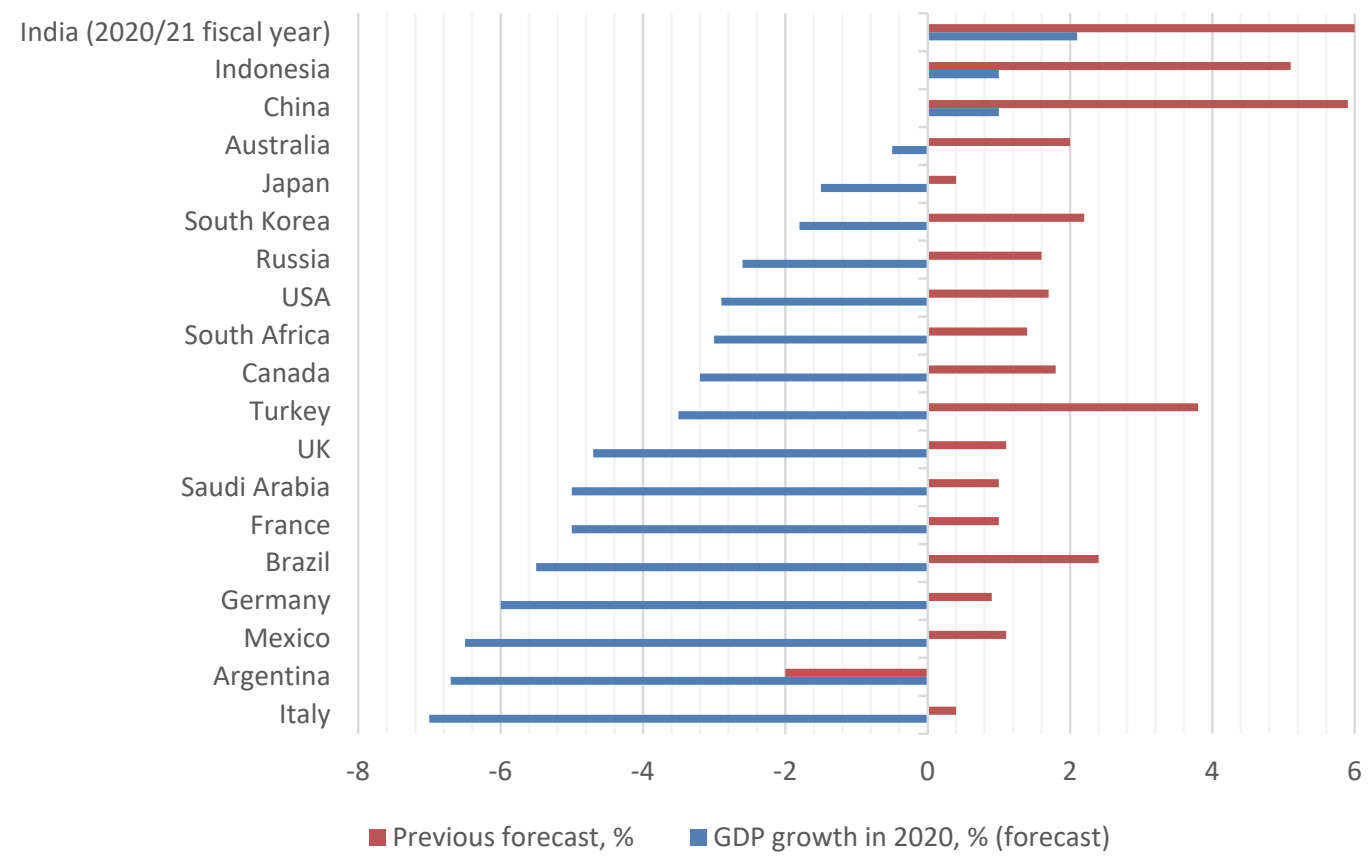

Fig. 4. GDP growth forecast in 2020 Source: EIU (2020)

According to OECD (2020a) estimates, for each month of containment, there will be a loss of 2 percentage points in annual GDP growth. The lockdown exerts the most adverse effect on the tourism sector that faces an output decrease as high as $70 \%$. Global international tourist arrivals will be down by $20-30 \%$, which translates into a loss of $\$ 30-\$ 50$ billion in spending by international visitors (UNWTO, 2020b). Industries more reliant on high social interaction - air carriers, hotel companies, entertainment and moviemakers - are among the hardest hit (Segal \& Gerstel, 2020).

Countries reliant on agriculture and mining will be comparatively less vulnerable, but will still face challenges as global demand for commodities decreases due to reduced production. Moreover, an increase in the unemployment rate was recorded in some countries (in March, in the USA it rose by $0.9 \%$, in Austria - by more than two thirds, in Norway levels of registered unemployed saw a fivefold increase (OECD, 2020b)). This will result in a drop in demand for end products and services, which will serve as an additional factor in production cutbacks and GDP fall.

\subsection{Development prospects}

The changes in society behavior adopted during the COVID-19 outbreak are forecast to have long-term consequences. Disruptions in normal economic activity due to the coronavirus pandemic have already led to a significant fall in international flows and global GDP. According to IMF forecast (IMF, 2020), the global economy is projected to contract sharply by $-3 \%$ in 2020, much worse than during the 2008-2009 financial crisis. In a baseline scenario, which suggests that 
the pandemic fades in the second half of 2020 and containment efforts can be gradually unwound, the global economy is expected to grow by $5.8 \%$ in 2021 in comparison with 2020 as economic activity normalizes. As forecast by the WTO experts (WTO, 2020), global trade in 2020 is expected to drop by between 13\% and 32\% in positive and negative scenario, respectively. The latest analysis by the United Nations World Tourism Organization (UNWTO, 2020a) indicates that 45\% of destinations have totally or partially closed their borders for tourists; $30 \%$ have suspended totally or partially international flights; and $18 \%$ are banning the entry for passengers from specific countries of origin. Unprecedented travel restrictions will result in a decline in the number of foreign tourists by $20-30 \%$ in 2020 if compared with the level of 2019 , which is significantly higher (by 4\%) than the cuts in the tourist flow during the 2008-2009 crisis and the outbreak of SARS in 2003 (by $0.4 \%$ ) (Table 4$)$.

Table 4

Projected dynamics of international flows and GDP in 2020-2021

\begin{tabular}{|c|c|c|c|c|}
\hline \multirow[t]{3}{*}{ Flow } & \multicolumn{4}{|c|}{ Annual change to the previous year, $\%$} \\
\hline & \multicolumn{2}{|c|}{ Optimistic scenario } & \multicolumn{2}{|c|}{ Pessimistic scenario } \\
\hline & 2020 & 2021 & 2020 & 2021 \\
\hline Trade flow & $-12.9 \%$ & $21.3 \%$ & -31.9 & 24 \\
\hline Investment flow & $-5 \%$ & & $-15 \%$ & \\
\hline Information flow & $5 \%$ & $8 \%$ & & \\
\hline Population flow (tourism) & $-20 \%$ & & $-30 \%$ & \\
\hline Global GDP & $-3 \%$ & $5.8 \%$ & & \\
\hline
\end{tabular}

In contrast to other flows, the pandemic positively affected globalization of the information flow by swelling the volume of cross-border Internet traffic and other communications. Social networks, e-commerce companies and new platforms received an additional impetus. Organizations and individuals are expected to use digital solutions more actively, since they acquire new habits during the crisis (UNCTAD, 2020b). At the same time, according to Cisco (2020), an increase in the information flow will be constrained by the overall fall in business activity and a drop in population income. With a significant slowdown in trade, investment and population flows, a slight rise in the information flow will not have a dramatic effect on globalization processes and will be unable to block the general trend towards a decrease in the Index of Globalization.

\section{Conclusion}

The assessment of globalization has shown that trade and investment components have lost their positions, whereas the information and population flows have expanded. The prevailing trend indicates a gradual slowdown in globalization. The financial crises of 2000-2001 and 2008-2009 are illustrative periods. Despite the fact that at the time of writing this article the COVID-19 pandemic had not been localized, some key trends in the development of globalization suggest a fall in globalization at the next stage. Coronavirus-driven disruptions in global economic activity have already caused a marked reduction in international flows and global GDP.

\section{References}

Akberdina, V., Kalinina, A., \& Vlasov, A. (2018). Transformation stages of the Russian industrial complex in the context of economy digitization. Problems and Perspectives in Management, 16(4), $201-211$. https://doi.org/10.21511/ppm.16(4).2018.17

Ali, A., \& ur Rehman, H. (2018). Macroeconomic instability and its impact on gross domestic product: An empirical analysis of Pakistan. Journal of Eurasian Economic Dialogue, 1(3), 43-62.

Altman, S. A., Bastian, P. (2019). Growth in first gear: What's next for globalization? Retrieved from https://www.dhl.com/global-en/home/about-us/delivered-magazine/articles/2020/issue-1-2020/growth-in-first-gearwhats-next-for-globalization.html

Andersen, T. M., \& Herbertsson, T. T. (2003). Measuring globalization. Discussion Paper No. 817. July, 2003. Bonn, Germany.

Arribas, I., Perez, F., \& Tortosa-Ausina, E. (2009). Measuring globalization of international trade: Theory and evidence. World Development, 37(1), 127-145. https://doi.org/10.1016/j.worlddev.2008.03.009

Ayhan Kose, M., Prasad, E., Rogoff, K., \& Wei, S.-J. (2006). Financial globalization: A reappraisal. IMF Working Papers, vol. 189. https://doi.org/10.3386/w12484

Bereznoy, A. V. (2018). Multinational business in the era of global digital revolution. World Economy and International Relations, 62(9), 5-17. https://doi.org/10.20542/0131-2227-2018-62-9-5-17

Caselli, M. (2006). On the nature of globalization and its measurement. Some notes on the AT Kearney Foreign Policy Magazine Globalization Index and the CSGR Globalization Index. UNU-CRIS Occasional Papers. Universita Cattolica del Sacro Cuore, Milano. 
Chinn, M. D., \& Ito, H. (2008). A new measure of financial openness. Journal of Comparative Policy Analysis: Research and Practice, 10, 309-322. https://doi.org/10.1080/13876980802231123

Chumakov, A. N. (2014). On globalization objectively. Age of Globalization, 2, 39-51.

Cisco. (2020). Annual Internet Report 2018-2023. White Paper. March 9. Retrieved from https:/www.cisco.com/c/en/us/solutions/collateral/executive-perspectives/annual-internet-report/white-paper-c11741490.html

D'Urbino, L. (2019). The steam has gone out of globalization. The Economist, January 24. Retrieved from https:/www.economist.com/leaders/2019/01/24/the-steam-has-gone-out-of-globalisation

Donnan, S., \& Leatherby, L. (2019). Globalization isn't dying, it's just evolving. Retrieved from https://www.bloomberg.com/graphics/2019-globalization/

Dreher, A. (2006). Does globalization affect growth? Evidence from a new Index of Globalization. Applied Economics, 38(10), 1091-1110. https://doi.org/10.1080/00036840500392078

Dreher, A., Gaston, A., \& Martens, P. (2008). Measuring globalization. Gauging its consequences. Springer Verlag. https://doi.org/10.1007/978-0-387-74069-0

Dreher, A., Gaston, N., Martens, P., \& Van Boxem, L. (2010). Measuring globalization - opening the black box. A critical analysis of globalization indices. Journal of Globalization Studies, 1(1), 166-185.

EIU. (2020). COVID-19 to send almost all G20 countries into a recession. Retrieved from https://www.eiu.com/n/covid19-to-send-almost-all-g20-countries-into-a-recession/

Friedman, T. L. (2005). It's a flat world, after all. New York Times Magazine, April 3.

Gichiev, N. S. (2014). The integral globalization index. Regional Problems of Economy Transformation, 5(43), 79-84.

Hadili, A., Raab, R., \& Wenzelburger, J. (2016). Trade liberalization in Arab Maghreb Union countries. Journal of Eurasian Economic Dialogue, 1(3), 14-27.

Hammes, T. (2016). The end of globalization? The international security implications. August. Retrieved from https://warontherocks.com/2016/08/the-end-of-globalization-the-international-security-implications/

Huh, H.-S., Park, C.-Y. (2019). A new index of globalization: Measuring impacts of integration on economic growth and income inequality. ADB Economics Working Paper Series. No. 587. https://doi.org/10.22617/WPS190245-2

IMF. (2020). World Economic Outlook. The Great Lockdown. Retrieved from https://www.imf.org/en/Publications/WEO/Issues/2020/04/14/weo-april-2020

Kheyfets, B. A. (2018). Metamorphosis of economic globalization. Moscow: Institute of Economics of the RAS.

King, S. (2017). Grave new world: The end of globalization, the return of history. New Haven: Yale University Press.

Lankauskiene, T., \& Tvaronavičiene, M. (2012). Security and sustainable development: Approaches and dimensions in the globalization context. Journal of Security and Sustainability Issues, 1(4), $287-297$. https://doi.org/10.9770/jssi.2012.1.4(5)

Litau, E. (2017). Evolution of species' in business: From mice to elephants. The question of small enterprise development. Journal of Advanced Research in Law and Economics, 8(6), 1812-1824. https://doi.org/10.14505/jarle.v8.6(28).16

Litau, E. (2018). The information problem on the way to becoming a "Gazelle." In Proceedings of the European Conference on Innovation and Entrepreneurship, ECIE (Vol. 2018-September, pp. 394-401).

Lund, S., Manyika, J., \& Bughin, J. (2016). Globalization is becoming more about data and less about stuff. Harvard Business Review, March 14. Retrieved from https://hbr.org/2016/03/globalization-is-becoming-more-about-data-andless-about-stuf

Makreshanska-Mladenovska, S., \& Petrevski, G. (2017). Decentralization, fiscal transfers and income inequality in Central and Eastern European countries. Journal of Eurasian Economic Dialogue, 2(6), 44-54.

Martens, P., Dreher, A., \& Gaston, N. (2008). The Global Village and the social and cultural aspects of globalization. GDC Working Papers, vol. 17.

Maslov, S. (2001). Measures of globalization based on cross-correlations of world financial indices. July, 6. https://doi.org/10.2139/ssrn.276111

OECD. (2018). TiVA 2018 introductory flyer: Insights from TiVA and related indicators. Retrieved from https://www.oecd.org/sti/ind/measuring-trade-in-value-added.htm\#country-notes

OECD. (2020a). OECD updates G20 summit on outlook for global economy. Retrieved from https://www.oecd.org/newsroom/oecd-updates-g20-summit-on-outlook-for-global-economy.htm

OECD. (2020b). Harmonised Unemployment Rates (HURs). April. Retrieved from http://www.oecd.org/sdd/labourstats/harmonised-unemployment-rates-oecd-update-april-2020.htm

Orazbayev, S. (2017). Immigration barriers and net brain drain. Journal of Eurasian Social Dialogue, 2(1), 34-59.

Randolph, J. (2001). G-index: Globalisation measured. World Markets Research Centre.

Robinson, W. (2011). Globalization and the sociology of Immanuel Wallerstein: A critical appraisal. International Sociology, 26(6), 723-745. https://doi.org/10.1177/0268580910393372

Romanova, O. A., Korovin, G. B., \& Kuzmin, E. A. (2017). Analysis of the development prospects for the high-tech sector of the economy in the context of new industrialization. Espacios, 38(59), 25.

Savina, G., Haelg, F., Potrafke, N., \& Sturm, J.-E. (2019). The KOF Globalisation Index - Revisited. The Review of International Organizations, 14(3), 543-574. https://doi.org/10.1007/s11558-019-09344-2

Segal, S., Gerstel, D. (2020). The Global Economic Impacts of COVID-19. March 10. Retrieved from https://www.csis.org/analysis/global-economic-impacts-covid-19

Sensortower. (2020). Store Intelligence Data Digest Q1 2020. Retrieved from https://sensortower.com/ 
Sheffield, J., Korotayev, A., \& Grinin, L. (2013). Globalization: Yesterday, today, and tomorrow. USA: Emergent Publications.

Shulgin, S., Zinkina, J., \& Andreev, A. (2019). Measuring globalization: Network approach to countries' global connectivity rates and their evolution in time. Social Evolution \& History, 18(1). https://doi.org/10.30884/seh/2019.01.07

Simonova, M. D. (2009). Economic globalization indicators: The OECD Methodological Framework. Economic Sciences, 10(59), 394-398.

The ACH. (2020). The Accounts Chamber of the Russian Federation. How coronavirus is changing work with technology: Switching to remote work, robots, neural networks and cybersecurity. Retrieved from http://www.ach.gov.ru/news/kakkoronavirus-menyaet-rabotu-s-tekhnologiyami-perekhod-na-udalenku-roboty-neyroseti-i-kiberbezopas

Tvaronavičiene, M., Grybaite, V., \& Tunčikiene, Z. (2013). Globalization drivers in developed and less developed countries: If consistent patterns can be traced. Journal of Security and Sustainability Issues, 2(4), 5-11. https://doi.org/10.9770/jssi.2013.2.4(1)

UNCTAD. (2020a). Impact of the coronavirus outbreak on global FDI. Retrieved from https://unctad.org/en/PublicationsLibrary/diaeinf2020d2 en.pdf

UNCTAD. (2020b). The COVID-19 crisis: Accentuating the need to bridge digital divides. Retrieved from https://unctad.org/en/pages/PublicationWebflyer.aspx?publicationid=2701

University of Warwick. (n.d.). The CSGR Globalisation Index. Centre for the Study of Globalisation and Regionalisation. Retrieved from https://warwick.ac.uk/fac/soc/pais/research/researchcentres/csgr/index

UNWTO. (2020a). 100\% of global destinations now have COVID-19 travel restrictions. Retrieved from https://www.unwto.org/news/covid-19-travel-Retrieved from restrictions

UNWTO. (2020b). Tourism and COVID-19. April, 14. Retrieved from https://www.unwto.org/tourism-covid-19

Vujakovic, P. (2010). How to measure globalisation? A New Globalisation Index (NGI), Atlantic Economic Journal, $38(2)$, 237. https://doi.org/10.1007/s11293-010-9217-3

Watanabe, M., Miyake, Y., \& Yasuoka, M. (2018). Unemployment, income growth and social security. Journal of Eurasian Economic Dialogue, 3(3), 21-30.

WTO. (2020). Trade set to plunge as COVID-19 pandemic upends global economy. Retrieved from https://www.wto.org/english/news e/pres20 e/pr855 e.htm

Zeibote, Z., Volkova, T., Todorov, K. (2019). The impact of globalization on regional development and competitiveness: Cases of selected regions. Insights into Regional Development 1(1), 33-47. https://doi.org/10.9770/ird.2019.1.1(3)

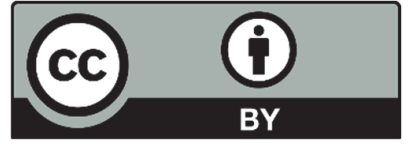

(C) 2020 by the authors; licensee Growing Science, Canada. This is an open access article distributed under the terms and conditions of the Creative Commons Attribution (CC-BY) license (http://creativecommons.org/licenses/by/4.0/). 